\title{
Resilience of Adolescents Diagnosed with Anxiety and Their Parents in Clinical Sample
}

\author{
Krisztina Törő \\ Szabolcs Takács \\ Gábor Csikós \\ Károli Gáspár University of the \\ Reformed Church, Psychology Institute
}

\section{Abstract}

Anxiety disorder is the most frequent psychiatric problem among children and adolescents. Research proved that resilience can be a protective factor in coping with psychological difficulties. Our research focuses on these aspects of resilience. Aims: We aimed to investigate the resilience and anxiety level of families with adolescents who were diagnosed with anxiety disorders. The clinical sample included 40 adolescents who were diagnosed with anxiety disorders and who received ambulant treatment. (18 boys and 22 girls; age: $\mathrm{M}=13.37$ years, $\mathrm{SD}=1.46$ ). Members of the control group were recruited from schools and they were normally developing adolescents without any psychiatric diagnosis. (18 boys and 19 girls, age: $\mathrm{M}=13.7$ years; $\mathrm{SD}=1.56$ ) DASS-21, Ten items Connor-Davidson Resilience Scale and self-made demographic sheet were used. Regarding the resilience, a Significant difference was found between the clinical and the sample group both among the mothers and their children. However, in the case of fathers, no discrepancy was found. Our results suggest that there is a significant, moderate positive relationship between the resilience of the mother and their children. Nevertheless, similar mechanisms in the fathers' case cannot be registered. In the control group, the fathers' perception of their child's resilience proved to be the strongest predictive factor (beta=0,495). On the contrary in the clinical group, the maternal perception was more accurate. (beta=0,06). Resilience can serve as a protective factor against anxiety. Our results can be useful for practitioners and draw attention to the importance of intrafamily mechanisms in coping with anxiety and mood disorders.

Keywords: Resilience of Adolescents Diagnosed with Anxiety and Their Parents in Clinical Sample 


\section{Introduction}

\section{On the anxiety disorder in childhood}

Anxiety disorder is the most frequent psychiatric problem among children and adolescents. However, these disorders are not equivalents to those in adulthood. Several researches showed that battling with anxiety disorders in childhood does not necessary carried to adulthood as many neurotic symptoms can be extremities within the normal development. While externalizing disorders cause difficulties for the social environment (Perczel, Kiss, Ajtay 2005), symptoms of childhood anxiety affect mainly the individual, so the majority can remain undiagnosed.

\section{Prevalence and epidemics:}

In the research of Costello and al. children (7-11 years) under medical treatment were examined. The prevalence of anxiety disorders was $8,9 \%$ in this population. (Costello, Egger, Angold 2004). The occurance of patological anxiety is twice more frequent among girls than boys. (Beesdo et al, 2009). Regarding the total population the prevalence of social phobia was $1 \%$, agoraphobia $1,2 \%$, separation anxiety $4,1 \%$ and specific phobias 9,2\% (Costello, Egger, Angold, 2004).

Anxiety can be explained by family cumulations and the effect of genetic factors seems to be marginal, although they can play role in the occurance of predisposition (Hettema et al, 2001).

\section{The role of parents in the ontology of anxiety disorders}

Several studies claimed that anxiety disorders have cumulative effects within the family. The occurance of anxiety among children is higher when a parent - especially the mother - also battles with this disorder (McClure, Brennan, Hammen, Brocque, 2001). The mechanism can be explained by social learning theory (Bögels, van Dongen, Muris, 2006) that suggest that the parental stress tends to interpret situations as threats and follows the parent's avoidant and anxious behavior (Rapee, Schniering, Hudson, 2009). Nevertheless, overprotecting parental attitude also helps the development of specific fobia, panic disorder and generalized anxiety. (Kendler, Davies, Kessler, 1997 cited by Beesdo, Knappe, Pine, 2009) Parent-child relationship that is burdened by conflicts and discord also raises the prevalence of anxiety disorders (Rueter, Scaramella, Wallace, 1999 cited by Beesdo, Knappe, Pine, 2009).

\section{Resilience among adolescents}

Nowadays increasing number of studies focus on resilience. This is an adaptive, stressresistent predisposition that helps adaptation even in hard times. The concept refers the process of overcoming negative effects, successful copong with traumas and avoiding the negative trajectories associated with risks (Fergus, Zimmerman, 2005). According to Dowrick and his collegues (2008) changing in lifestyle, the selfhelp attitude, the support of family members and friends helped teenagers the most in recovery from anxiety and depression. Resilience could accelerate these processes 
by the improvement of quality of life through promoting health protecting behaviours. Hauser (2006) found that three factors promoted the recovery from psychiatric disorders for adolescent girls: personal influence (they were able to change their situation), inner focus (they cope their inner feelings and thoughts) and establishing supportive relationships.

Norwegian research showed that higher level of resilience corralted with lower levels of anxiety, depression and obsessive-compulsive disorder (Hjemdal et al 2011). Recent study of Nagy and F. Lassú (2017) focused on inhabitants in childen's home who could cope efficiently with difficulties in life. They showed high competency in regulating emotions and impulses and were able to reframe even troublesome life situtations. They were open to spiritual experiences and expressed gratitude toward the social workers, friends or other benefactors.

So, according to the literature the resilience proves to be an important factor in coping with anxiety and other psychiatric disorders. Therefore, our study focuses on this psychological factor in the case of adolescents who were taking ambulant care after their diagnosis with anxiety disorder. We aim to elaborate the phenomenon within the dynamics of the family microsystem.

\section{Aims}

1. The examination of resilience among adolescents who were diagnosed by anxiety disorders

2. The comparison of resilience among adolescents and their parents

3. The effect of parental resilience on the resilience of the adolescent

Methods

\section{Participants}

Parents and their children between 12 and 17 participated in the research. Data collection period endured from June to December 2020. Children with anxiety disorder were outpatients of the Kertváros Pszichológiai Rendelő, Budapest. They were diagnosed but not yet treated. The control group was formed by normally developing children from primary and secondary schools in Budapest.

Criteria for the inclusion into the clinical group was anxiety disorder diagnosis based on the children's answers in DASS-21 (Lovibond 1995). Other comorbid disorders were explored from the previous clinical documentation. Inclusion into to control group was the lack of psychiatric history. Mental retardation our autistic symptoms were criteria for exclusion in both cases.

The research was permitted by the Medical Research Council (Egészségügyi Tudományos Tanács Tudományos és Kutatásetikai Bizottság; ETT, TUKEB). All the participants were informed about the research both in writing and orally. 


\section{Tools}

a. Demographic sheet

Parents first provided basic demographic information, such as level of education, financial situation, the occurance of mental disorders within the family, numbers of siblings etc.

\section{b. DASS - 21 Scale}

The Depression, Anxiety and Stress Scale - 21 Items (DASS-21) is a multidimensional self-report scale designed to measure the negative emotional states of depression, anxiety and stress. The simple statements of the survey are easily comprehended by adolescents over 12 years and it makes diagnosis quick (five-ten minutes) and flexible. Dass-21 uses a dimensional concept of psychological disorders and suggests severity labels from normal to extremely severe. Hungarian adaptation of the scale was delivered by Mária Szabó on a sample of 1000 participants (Lovibond and Lovibond, 1995).

\section{c. Ten item Connor-Davidson Resilience Scale}

Connor-Davidson Resilience Scale (CD-RISC) was developed to measure resilience and positive adaptation after a stressful situation. The higher score on this scale represents higher level of resilience (Járai és mtsai, 2015; Kiss et al 2015). In our study parents filled this scale both on themselves and on their child.

\section{Results}

\section{Sample}

Clinical sample included 40 adolescents who were diagnosed by anxiety disorders and who received ambulant treatment. (18 boys and 22 girls; age: $M=13.37$ years, $\mathrm{SD}=1.46)$. Members of the control group were recruited from schools and they were normally developing adolescents without any psychiatric diagnosis. (18 boys and 19 girls, age: $\mathrm{M}=13.7$ years; $\mathrm{SD}=1.56$ ) Age distribution between the two groups is normal, there is no significant difference $(\mathrm{F}=0.346$ and $\mathrm{p}=0.558)$.

\begin{tabular}{|l|l|l|}
\hline Variables & Clinical group & Control group \\
\hline Father's education & 12 & 5 \\
\hline Elementary & 21 & 19 \\
\hline Intermediate & 7 & 13 \\
\hline Higher & 11 & 5 \\
\hline Mother's education & 22 & 19 \\
\hline Elementary & 7 & 13 \\
\hline Intermediate &
\end{tabular}

Table 1: Educational level of the parents 


\section{Anxeity indicators and comorbid diagnoses in the clinical group}

All members of the control group provided normal level of anxiety according to their answers on DASS - 21. However, those in the clinical group showed moderate (2), severe (29) or extremely severe (9) symptoms. Table 1 contains the comborid diagnoses based on their medical history. At the time of the research they were participating in the diagnosis project and not yet received (medical) treatment.

Diagnosed psychiatric disorders prevalence: member and \%

\begin{tabular}{l|ll}
\hline Anxiety disorders & \multicolumn{3}{l}{} \\
\hline obsessive disorder & 6 & 15 \\
\hline social fobia & 6 & 15 \\
\hline panic disorder & 5 & 12.5 \\
\hline generalized anxiety disorder & 3 & 7.5 \\
\hline separation anxiety & 12 & 30 \\
\hline posttraumiatic stress syndrome & 11 & 27,5 \\
\hline Other psychological disorders & 10 & 25 \\
\hline dysthymia & 7 & 17,5 \\
\hline behavirural disorder & 6 & 15 \\
\hline hypomania & 12 & 30 \\
\hline major depression & \multicolumn{2}{|l}{}
\end{tabular}

Table 2: Comborbid diseases among the members of the clinical group $(n=40)$ based on their medical history

The sample indicates that the occurance of psychiatric disorders within the family is significantly higher in the clinical group than in the control. ( $B M=-2,591 p=0,0119$ )* (Table 3)

\begin{tabular}{|c|c|c|c|c|c|c|}
\hline & \multirow[t]{2}{*}{ Members } & \multirow{2}{*}{$\begin{array}{l}\text { Mean of } \\
\text { ranks }\end{array}$} & \multirow{2}{*}{$\begin{array}{l}\text { Deviation of } \\
\text { ranks }\end{array}$} & \multicolumn{3}{|c|}{ Kolmogorov test } \\
\hline & & & & Dmax & $\mathrm{D}^{*}$ & $\mathrm{p}$ \\
\hline $\begin{array}{l}\text { Clinical } \\
\text { group }\end{array}$ & 40 & 43,13 & 10,38 & 0,191 & 1,206 & 0,1092 \\
\hline $\begin{array}{l}\text { Control } \\
\text { group }\end{array}$ & 37 & 34.54 & 18,05 & 0,125 & 0,759 & 0,6126 \\
\hline
\end{tabular}

Table 3: Occurance of psychiatric disorders in the families within the clinical and control group (based on the demographic sheets)

\section{Resilience of parents and their children in the clinical and control group}

The results on CD-RISK Scale is presented as it follows (Table 4):

\begin{tabular}{l|l|l|l|l|l|l|l|l} 
& \multicolumn{4}{|l|}{ Adolescents } & \multicolumn{2}{l|}{} & \multicolumn{2}{l}{ Parents } \\
Resilience & Mean & min. & max. & SD & boy & girl & mother & father \\
\hline Clinical & 22.68 & 18 & 30 & 2.576 & & & 22.27 & 23.20 \\
\hline Control & 29.3 & 18 & 35 & 4.390 & & & 29.30 & 25.97 \\
\hline Total sample & 25.86 & 18 & 35 & 4.860 & 26.8 & 25.07 & 25.65 & 24.53
\end{tabular}

Table 4: The deviation of means on CD-RISK, adolescents and parents 
The optimal zone of resilience is between 25 and 35 points, and as the table shows the average of the control group remains within this zone. However, resilience of both the adolescents and their parents in the control group is shown low by this scale. Differences can be registered between the clinical and the control group regarding the resilience (see Table 5). Maternal results show normal distribution both in clinical and control group. However, deviation was not homogenous. Therefore Levene's test was used $\left.F(1 ; 59,2)=13,428(p=0,0005)^{* * *}\right)$. Results of the Welch's $d$ test are: $d(61,3)=9,882(p=0,0000)^{* * *}$ So, regarding the mothers there is a signficiant difference between the two groups. The Cohen's $d$ effect size $(d=2.207)$ suggest that this discrepacne is notable. However, no difference can be detected between the results of the fathers'.

\begin{tabular}{|c|c|c|c|c|c|c|c|}
\hline & $\mathrm{N}$ & mean & STDEV & SKEW & KURT & $\begin{array}{l}\text { Kolgomorov-Smirnov } \\
\text { test (p) }\end{array}$ & $\begin{array}{l}\text { Levene test } \\
(\mathrm{p})\end{array}$ \\
\hline clinical & 40 & 22.7 & 2.58 & 0.374 & 0.644 & 0.095 & 0.001 \\
\hline control & 37 & 29.3 & 4.39 & 0.388 & $\begin{array}{l}- \\
0.187 \\
\end{array}$ & 0.004 & \\
\hline total & 77 & 25.9 & 4.86 & 0.347 & $\begin{array}{l}- \\
1.079\end{array}$ & 0.003 & \\
\hline
\end{tabular}

Table 5 Differences between adolescents in the clinical and control group regarding their results on CD-RISK

\section{The relation between the parental and children's resilience}

Our results suggest that there is a significant, moderate positive relation between the resilience of the mother and their children. Regarding the control group there is $57,4 \%$ chance for finding good performance on the resilience scale in both the cases of mothers and their children. Hower, good maternal performance combined with poor results by their children appears only in 23,1\% of the cases. (p_poz = $57,4 \%$, p_neg $=23,1 \%$ ) Similar results can be detected in the clinical group too (p_poz $=60,4 \%$, p_neg $=21,7 \%$ ), so it might be assumed that higher maternal resilience comes with the higher resilience of their children. Nevertheless, similar mechanisms in the fathers' case cannot be registered.

\section{The children's resilience as perceived by their parents}

In the control group the fathers' perception of their child proved to be the strongest predictive factor (beta $=0,495$ ). In contrary in the clinical group, the maternal perception was more accurate. (beta=0,06). For the details see Table 6 .

\begin{tabular}{|l|l|l|l|l|l|}
\hline & $\begin{array}{l}\text { Variables of } \\
\text { the model }\end{array}$ & $\begin{array}{l}\text { Non- } \\
\text { standardized } \\
\text { coefficients }\end{array}$ & $\begin{array}{l}\text { Standardized } \\
\text { coefficients }\end{array}$ & $\mathrm{t}$ & $\mathrm{p}$ \\
\hline & & $\mathrm{B}$ & $\begin{array}{l}\text { Standard } \\
\text { error }\end{array}$ & Beta & \\
\hline $\begin{array}{l}\text { Control } \\
\text { group }\end{array}$ & Constant & 4.680 & 7.641 & & 0.612 \\
\hline
\end{tabular}




\begin{tabular}{|l|l|l|l|l|l|}
\hline & $\begin{array}{l}\text { Father on the } \\
\text { child }\end{array}$ & 0.859 & 0.266 & 0.495 & 3.226 \\
\hline Clinical group & Constant & 13.870 & 1.933 & & 7.174 \\
\hline & $\begin{array}{l}\text { Mother on the } \\
\text { child }\end{array}$ & 0.395 & 0.086 & 0.600 & 4.622 \\
\hline
\end{tabular}

Table 6: Resilience of children in the control and clinical group after linear regression

\section{Discussion}

This study draws the attention to the importane of diagnosing anxiety and finding the most adequate treatment. Adolscents battling with anxiety disorder frequently produce other symptoms, that might hide the core problems. So accurate differential diagnosis is pivotal in the healing process. Nowadays, therapies focusing on anxiety and depression are highly efficient as the $70-80 \%$ of the patients recover. (Torzsa et al, 2009)

The clinical group enforces the findings of the litterature that anxiety disorder commonly coexsist with other psychological disorders (mostly dysphoria). The occurance of major depressive episodes rises the risk of alchol or drog abuse, (Kazdin, 1994) and generalized anxiety disorder is strongly associated with other comorbidities of panic disorders depressoin, dysthima, social or special fobias ( Brown \& Barlow, 1992; Sanderson, Beck, \& Beck, 1990; Brown et al, 2001) .

Resilience plays an important factor in recovery from anxiety disorders. (Kiss 2015) Our results show that the resilience of children and their parents in the clinical group is significantly lower than in the control group, and remains under the optimal zone. Resilience can be used as a resource in therapy. (Masten, 2001, Gyöngyösiné Kiss et al, 2008) Improving resilience is contributed by phsycal activity, optimist attitudes, self-confidence, spirituality and finding purposes in life. In contrary low level of resilience increases perceived stress and the use of maladaptive coping mechanisms like repression, rumination, self-reproach or even aggression (Deák 2015).

It seems trivial that those who are generally not in a state of angst provide higher levels of reseilience. But this should not lead to the conclusion that they can be left alone because they can manage all the hardships. Pivotal factors in improving resilience are strong family bounds and abundant friend relationships (Skrove, Romundstad, Indredavik, 2012). Our results also emphasize the importance of family features. The level of maternal resilience was significantly lower in the clinical than in the control group. Fathers did not show any differences.

The way how family as a microsystem reacts to the circumstances deeply affects the attitudes and coping of the family members as individuals. Resilient families tend to communicate openly and cooparte in solving problems. They also try to remain positive and emotionally warm and frequently use spiritual points of view in understanding their current difficulties. Resilient families encourining the maintance 
of interpersonal relationships and they are efficient in mobilizing resources even from outside the family (Walsh, 2003). Economic stability and shared time contribute resilience. Jennifer A. Theiss (2018) drew the attention to the importance of child parent communication. Parents who accept the feeling of their children and show an example how one can express and react to feelings are cultivitating the resilience of the children who will be more efficient in managing negative life events (Gottmann, 2001 cited by Theiss 2018) Parental support can be emotional or informative. The first serves as emotional support, while the latter helps them in detecting situations and behaviours that carry risks (Fergus, Zimmermann, 2005). Other researches emphasized the importance of the father's support which can be a protective factor among adolescents against depression or suicde thoughts. (Tarver, Wong, Neighbors, Zimmerman, 2004 cited by Zimmermann et al., 2013)

Children who live in conflict-prone family environment have lower level of selfconfidence. The angry or cold reactions of the parents will be part of the self-image of the children. Adolescents with highly critical mothers generally show lower level of self-esteem than those who have supportive mothers. (Neff, McGehee, 2010).

Family relationships alone can influence the inner feelings of its members (Hjemdal, Vogel, Solem, Stiles, 2011). The study of Bögels, van Dongen and Muris suggested that children learn coping by social learning and the most important role models in this process are the parents. (Bögels, Oosten, Muris, Smulders, 2001) So, it can be assumed that the parental resilience have a direct effect on the children's anxiety. Parents with low resilience generally offer negative schemes for their children that are unsufficient tools in coping hardships and therefore they rise frustration and feeling anxiety. Unfortunately, disharmonic families deprive children from other sources of coping including strong family structures or supportive relationships among the family members. (Zolkoski and Bullock, 2012). Percieved dissconance within a family directly effects the feeling of insecurity and contributes to the occurance of problems related to both externalizating and internlizating (Forman and Davies, 2003).

The attachment between father and child is shaped by those factors - acitivity, selfconfidence, sense of purpose (Psychogiou et al, 2008), - that are measured by the Connor-Davidson scale. Our results show that fathers are more accurate in estimating their children's resilience than the mothers. This result enforces those researches that emphasize the importance of the paternal role in the children's development. It carries an important message to the professionals to helpi improving not only the mother-child relationship but focus on the fathers too.

The main limit of this research is the relatively low number of members within the clinical group. However, this is possibly compensated by personal testing and the involvement of families which opened the opportunity to investigate inter-family effects. Our findings provide useful evidences for promoting family therapy in healing anxiety disorders. 


\section{References}

[1] Beesdo K., Knappe S., Pine D. S. (2009). Anxiety and anxiety disorders in children and adolescents: developmental issues and implications for DSM-V. Psychiatric Clinics of North America, 32(3), 483-524.

[2] Bögels, S. M., van Oosten, M., Muris, P., \& Smulders, D. (2001). Familial correlates of social anxiety in children and adolescents. Behaviour Research and Therapy 39, 273-287.

[3] Brown, T. A., \& Barlow, D. H. (1992). Comorbidity among anxiety disorders: Implications for treatment and DSM-IV.. Journal of Consulting and Clinical Psychology, 60(6), 835-844

[4] Costello. E. J., Egger, H. L., \& Angold, A. (2005). The developmental epidemiology of anxiety disorders: phenomenology, prevalence, and comorbidity. Child and Adolescent Psychiatric Clinics of North America, 14(4), 631-648.

[5] Deák, I. F. (2015). A családi környezet szerepe az egyén reziliens alkalmazkodásának kialakulásában. Erdélyi Társadalom, 13(01), 163-168.

[6] Dowrick, C., Kokanovic, R., Hegarty, K., Griffiths, F., \& Gunn, J. (2008). Resilience and depression: perspectives from primary care. Health:, 12(4), 439-452.

[7] Fergus, S., \& Zimmerman, A. (2005). Adolescent Resilience: A Framework for Understanding Healthy Development in the Face of Risk. Annual Review of Public Health 2005. 26:399-419.

[8] Forman, E. M., \& Davies, P. T. (2003). Family instability and young adolescent maladjustment: The mediating effects of parenting quality and adolescent appraisals of family security. Journal of Clinical Child and Adolescent Psychology, 32(1), 94-105.

[9] Gyöngyösiné Kiss, E., Czirják L., Hargitai R., Nagy L., Paksi E. (2008): Egocontrol and egoresiliency in systemic autoimmune disorders (SSC, RA, SLE). Horizons of Psychology, Official Journal of the Slovenian Psychological Association, 17:supl., 8.

[10] Hauser S. T, Golden E., Allen J. P.(2006). Narrative in the Study of Resilience. The Psychoanalytic Study of the Child. 61:205-227.

[11] Hettema J. M., Prescott C. A., Kendler K. S.(2001). A population based study of generalizated anxiety disorder in men and woman.J Nerv Ment Dis.

[12] Hjemdal O., P. A. Vogel., S. Solem., K.Hagen., T.C. Stile.(2011).The Realitionship between Resilience and Levels of Anxiety, Depression, and Obsessive-Comulsive Symptomps in Adolescents. Clinical Psychology and Psychotherapy, 18, 314-321.

[13] Járai R., Vajda D., Hargitai R., Nagy L., Csókási K., Kiss E. (2015): ConnorDavidson Reziliencia Kérdív 10 itemes változatának jellemzői. Alkalmazott Pszichológia, 15(1):129- 126.

[14] Kazdin, A. E. (1994). Methodology, design, and evaluation in 
psychotherapy research. In A. E. Bergin \& S. L. Garfield (Eds.), Handbook of psychotherapy and behavior change (19-71). John Wiley \& Sons.

[15] Kiss E. Cs., Vajda D., Kaplár M., Csókási K., Hargitai R. és Nagy L. (2015).A 25-itemes Connor-Davidson Reziliencia Skála (CD-RISC) magyar adaptációja. Mentálhigiéné és pszichoszomatika, 16. 1. sz., 93-113.

[16] Lovibond, P. F., \& Lovibond, S. H. (1995). The structure of negative emotional states: Comparison of the Depression Anxiety Stress Scales (DASS) with the Beck Depression and Anxiety Inventories. Behaviour research and therapy, 33(3), 335-343

[17] Masten, A. S. (2001). Ordinary magic. Resilience processes in development. American

Psychologist, 56. 227-238.

[18] McClure, E. B., Brennan, P. A., Hammen, C., \& Le Brocque, R. M. (2001). Parental Anxiety Disorders, Child Anxiety Disorders, and the Perceived Parent-Child Relationship in an Australian High-Risk Sample. Journal of Abnormal Child Psychology, 29(1),1-10

[19] Nagy G.,F.Lassú Zs.(2017).Reziliens serdülők a gyermekotthonokban. Kapocs.XVI. évfolyam 73. lapszám 27-39.

[20] Neff, K. D., \& McGehee, P. (2010). Self-compassion and Psychological Resilience Among Adolescents and Young Adults. Self and Identity, 9(3), 225-240.

[21] Perczel D. F.,Kiss Z.,Ajtay G.(2005).Kérdőívek és becslőskálák a klinikai pszichológiában.Budapest:Országos Pszichiátriai és Neurológiai Intézet.

[22] Psychogiou, L., Daley, D., Thompson, M. J., \& Sonuga-Barke, E. J. (2008). Parenting empathy: Associations with dimensions of parent and child psychopathology. British Journal of Developmental Psychology, 26(2), 221232.

[23] Rapee, R. M., Schniering, C. A., \& Hudson, J. L. (2009). Anxiety Disorders During Childhood and Adolescence: Origins and Treatment. Annual Review of Clinical Psychology, 5, 311-341.

[24] Skrove, M., Romundstad, P., \& Indredavik, M. S. (2012). Resilience, lifestyle and symptoms of anxiety and depression in adolescence: the Young-HUNT study. Social Psychiatric and Psychiatric Epidemiology, 48(3):407-16.

[25] Theiss, J. A. (2018). Family communication and resilience. Journal of Applied Communication Research, 1479-5752.

[26] Torzsa P., Szeifert L., Dr. Dunai K., Dr. Kalabay L., Dr. Novák M.,(2009).A depresszió diagnosztikája és kezelése a családorvosi gyakorlatban.Budapest: Semmelweis

[27] Walsh, F. (2003). Family Resilience: A Framework for Clinical Practice. Family Process, 42(1), 1-18.

[28] Zimmermann, M. A., Stoddard, S. A., Eisman, A. B., Caldwell, C. H., Aiyer, S. M., \& Miller, A. (2013). Adolescent Resilience: Promotive Factors That Inform Prevention. Child Development Perspectives, (7)4, 215-220. 
[29] Zolkoski, S. M., \& Bullock, L. M. (2012). Resilience in children and youth: A review. Children and youth services review, 34(12), 2295-2303.

\section{Acknowledgements}

1; This research was financed by Károli Gáspár University of the Reformed Church. 